\title{
A revision of thirteen species of Triatominae (Hemiptera: Reduviidae) vectors of Chagas disease in Mexico
}

Revisión de 13 especies de la familia Triatominae (Hemiptera: Reduviidae) vectores de la

\author{
enfermedad de Chagas, en México
}

\author{
"Salazar-Schettino Paz Maria ${ }^{1}{ }^{* *}$ Rojas-Wastavino Gloria Elena ${ }^{1}$, Cabrera-Bravo Margarita ${ }^{1}$, \\ Bucio-Torres Martha IreneI ${ }^{1}$, Martínez-Ibarra José Alejandro ${ }^{3}$, Monroy-Escobar Maria Carlota ${ }^{2}$, \\ Rodas-Retana Antonieta ${ }^{2}$, Guevara-Gómez Yolanda ${ }^{1}$, Vences-Blanco Mauro Omar ${ }^{1}$ Ruiz-Hernández Adela Luisa ${ }^{1}$, \\ Torres-Gutiérrez Elia ${ }^{1}$
}

\begin{tabular}{|c|}
\hline Datos del Articulo \\
\hline $\begin{array}{l}{ }^{1} \text { Departamento de Microbiología y } \\
\text { Parasitología Facultad de Medicina, } \\
\text { Universidad Nacional Autónoma de } \\
\text { México. Edificio "A" } 2^{\circ} \text { Piso, Ciudad } \\
\text { Universitaria, México, DF. }\end{array}$ \\
\hline $\begin{array}{l}{ }^{2} \text { Universidad de San Carlos de } \\
\text { Guatemala, Laboratorio } \\
\text { Entomología Aplicada y Parasitología. }\end{array}$ \\
\hline $\begin{array}{l}3 \text { Área de Entomología Médica, Centro } \\
\text { Universitario del Sur, Universidad de } \\
\text { Guadalajara. Avenida Prolongación } \\
\text { Colon } \mathrm{s} / \mathrm{n} \mathrm{Km} 1 \text { Carretera Cd Guzmán- } \\
\text { Guadalajara Jalisco }\end{array}$ \\
\hline $\begin{array}{l}\text { *Dirección de contacto: Paz María } \\
\text { Salazar-Schettino. } \\
\text { E-mail. pazmar@servidor.unam.mx } \\
\text { Tel/fax (52) (55) } 56232468\end{array}$ \\
\hline $\begin{array}{l}\text { **Dirección de contacto: Gloria Elena } \\
\text { Rojas-Wastavino. } \\
\text { E-mail.daglo@servidor.unam.mx }\end{array}$ \\
\hline $\begin{array}{l}\text { Palabras clave: } \\
\text { Triatominos, } \\
\text { infección por Tripanosoma } \\
\text { cruzi, } \\
\text { comportamiento, } \\
\text { control, } \\
\text { México }\end{array}$ \\
\hline
\end{tabular}

J Selva Andina Res Soc 2010;1(1):57-80.

\section{Historial del artículo}

Received on June 10, 2010. Accepted on August 06, 2010. On line, Octuber 2010.

Key words:

\section{Triatominae,}

natural infection with

Trypanosoma cruzi

behaviour,

control,

Mexico.

\section{Resumen}

Los transmisores de Trypanosoma cruzi, flagelado causante de la enfermedad, se dividen en intradomiciliados, peridomiciliados y silvestres. Entre los intradomiciliados se encuentran, Triatoma barberi y Triatoma dimidiata, que son los que representan un mayor riesgo para la Salud Pública, en México. Aunque Triatoma dimidiata se encuentra principalmente dentro de la vivienda, en Yucatán tiene un comportamiento peridomiciliar, dentro de este grupo se encuentran la mayoría de los transmisores de la enfermedad de Chagas Meccus longipennis, M. mazzottii, M. pallidipennis, M. phyllosomus, M. picturatus, Triatoma gerstaeckeri, T. mexicana, T. rubida, Dipetalogaster máxima, Panstrongylus rufotuberculatus y Rhodnius prolixus. Los transmisores peridomiciliados son de menor riesgo en la dinámica de transmisión comparados con los intradomiciliados. Para el control de los transmisores intradomiciliados, se deben emplear programas de educación para la salud, mejoramiento de vivienda e insecticidas; mientras que para los vectores visitantes o peridomiciliados, son necesarios programas de educación para la salud, uso de mosquiteros, pabellones y cementación de las bardas de piedra.

(c) 2010. Journal of the Selva Andina Research Society. Bolivia. Todos los derechos reservados.

\section{Abstract}

Vectors of Trypanosoma cruzi, parasite responsible for Chagas disease, are divided in intradomestic, peridomestic and sylvatic. The intradomestic are Triatoma barberi and Triatoma dimidiata, two species that represent the highest health risk among the Mexican population. Triatoma dimidiata is a species found mainly inside human habitats, but in Yucatan, it corresponds to the peridomicile vectors. Also in the peridomicile most of Chagas disease vectors are found: Meccus bassolsae, M. longipennis, M. mazzottii, M pallidipennis, M. phyllosomus, M picturata, Triatoma gerstaeckeri, $T$ mexicana, $T$ rubida, Dipetalogaster máxima (the last two are in the process of becoming adapted to the domicile), Panstrongylus rufotuberculatus which occasionally enters the domicile in its adult stage, and Rhodnius prolixus, which is practically controlled in the country. Peridomestic vectors are of lower risk in the transmission dynamics, as compared to the intradomestic ones. For the control of the intradomestic vectors, health education programs, improvements of housing, and the use of pesticides are essential To control the peridomestic vectors, health education programs are required, as well as the use of mosquito nets on doors and windows and around beds, aside from cementing the stone wall fences. 


\section{Introduction}

There are several initiatives to control Chagas disease. In the Southern Cone Initiative (WHO 1992), the vector to control is Triatoma infestans; in the Andean and Central American Countries Initiatives (WHO 1997, 1998), the vectors to eradicate is Rhodnius prolixus and to control $T$ dimidiata. In the Mexico Initiative (Salazar et al 2001), no particular species is proposed, as there is a large variety of vectors distributed along the whole country, from the smallest one, Belminus costaricensis in Veracruz, to the largest, Dipetalogaster maxima in Baja California Sur (Salazar et al 1988). All these species have been related with Chagas disease (Cruz \& Pickering 2006).

In Mexico, 32 vectors of Trypanosoma cruzi have been reported, 19 species belong to the Triatoma genus and six to the Meccus genus, two species to the genus Panstrongylus, and one species to each of the following genera: Belminus, Dipetalogaster, Eratyrus, Paratriatoma, and Rhodnius. Two genera and fifteen species are exclusive of Mexico, one is Dipetalogaster with one species and the other is the Meccus genus with six species. The Triatoma genus has eight species that are only found in Mexico (Galvão et al 2003).

Thirteen vector species are related to human dwellings; two are found in the intradomicile and eleven in the peridomicile area (Vidal et al 2000). Intradomestic are Triatoma barberi and Triatoma dimidiata, although the latter has a similar behavior to that observed in the visiting vectors in the Yucatan Peninsula. The visiting vector species colonize the peridomicile, that is, $50-\mathrm{m}$ around the house (Bautista et al 1999) and accomplish some developmental stages of their life cycle in the intradomicile.

Dipetologaster maxima has a wild life cycle (Lent \& Wygodzinsky 1979), but it has been observed in the last years to be in a transition and adaptation process to the human housing. Of the eleven visiting species, only nymphs in the last stages and adults have been observed intradomiciliated; however, they do not colonize the human dwelling and their presence is not associated to any type of construction, they only enter the dwelling in search of food and, once obtained, they leave the dwelling. Meccus pallidipennis, M. longipennis, M. mazzottii and T. mexicana are species that we have found practically in all stages mainly in the first stages of their biological development, below stones or stone fences, indicating that this is the site where their biological cycle is accomplished.

Since not all stages of the biological cycle have been collected intradomicile, the colonization index proposed by Silveira et al (1984) and its modification by Diotaiuti et al (2000) does not reflect actually this index, even when finding nymphs in the fourth and fifth stage, the vector is not actually colonizing the human dwelling.

Altitude and temperature are important factors, because these vectors have no thermoregulatory center, and hence, both the vectors and the parasite are at the environmental temperature, which is going to influence the transmission dynamics of $T$. cruzi. The ideal temperature for the parasite is from 28 to $30^{\circ} \mathrm{C}$ a temperature that is not recorded at high altitudes.

Triatoma dimidiata is the most dispersed vector in Mexico, its presence has been reported in the south, 
center, east (Gulf of Mexico), and north of the country, for this reason in the Initiative of the Andean and Central American Countries (WHO 1997, 1998) only control of this species is proposed but not its eradication.

Seroprevalence values differ between the regions where intradomestic vectors are found and those where visiting vectors are reported. Concerning individuals that developed the disease, patients with myocardiopathies have been found in regions where visiting vectors are reported, and in those where $T$. barberi considered as intradomestic, is distributed; aside from this pathology, mega digestive organs have been reported (Salazar et al 1984a, Tay et al 1986).

The state of Oaxaca is worthwhile mentioning, especially for its historical antecedents regarding the disease and the variety of vectors found in this state, ten different triatomine species have been reported (Galvão et al 2003, Lent \& Wygodzinsky 1979, Carcavallo et al 1989, Ramsey et al 2000). Here, the first reports on the infected vector, reservoirs, and acute Chagas disease cases in humans were made (Mazzotti 1936, Mazzotti 1940) as well as the first chronic cases of myocardiopathy, megaesophagus, and megacolon (Salazar et al 1984a, Tay et al 1986, Salazar et al 1979). Goldsmith et al (1971) in a seroepidemiologic study of the coastal region in Oaxaca found $29.0 \%$ seropositivity; in one of the localities, the seroprevalence was of $76.0 \%$ in individuals older than 20 years and of $2.0 \%$ in children under the age of 10 years. Follow up another study was performed, in which the authors report $35.0 \%$ seropositivity in 124 individuals younger than 16 years, contrasting with the previous $2.0 \%$. The periods in which the authors find seronegative children between the first and second study coincide with DDT sprayings during the malaria eradication campaign (Goldsmith et al 1986) found $0.9 \%$ of seroprevalence; other surveys performed in the state of Oaxaca report seroprevalence between $7.8 \%$ and $25.3 \%$ (Tay et al 1986, Cortés et al
1985).

\section{Materials and methods}

This review was organized from available literature that includes research papers, conference abstracts, proceedings, theses, and original research conducted by the authors. The purpose of this review is to show same aspects about thirteen vectors, two are intradomestic and eleven are in the peridomestic area. The intradomestic are Triatoma barberi and Triatoma dimidiata, two species that represent the highest health risk among the Mexican population. The peridomestic are: Meccus longipennis, M. mazzottii, $M$ pallidipennis, M. phyllosomus, $M$ picturatus, Triatoma gerstaeckeri, T. mexicana, T rubida, Dipetalogaster maxima, Panstrongylus rufotuberculatus and Rhodnius prolixus.

\section{Results}

\section{Triatoma barberi (Usinger, 1939)}

This vector has only been report in Mexico (Figure 1), in the states of Colima, Guanajuato, Guerrero, Hidalgo, Jalisco, Michoacán, Morelos; Oaxaca, Puebla, Querétaro, Tlaxcala, and Veracruz (Salazar et al 1988, Salazar et al 2005b, Martínez et al 2008). It is the smallest of those dealt with herein; it is difficult to collect inside the domicile because it is very fast and hides in holes or fissures of the wall. It is finding at the highest altitude, from sea level to 2,000 masl (Carcavallo et al 1999) and 640 to 2,200 masl in Oaxaca (Ramsey et al 2000). The female measures 18.5 to $20 \mathrm{~mm}$ and the male 16 to $18 \mathrm{~mm}$ (Lent \& Wygodzinsky 1979).

Trypanosoma cruzi isolates obtained from this intradomiciliary vector are of high pathogenicity, as implied by the pathology shown by humans. It 
is more effective than $T$. dimidiata based on entomologic parameters, such as capacity of domiciliation, anthropophilic behavior, time interval between feeding, defecation, and the percentage of infecting forms in feces (Salazar et al 2005b). The natural infection index is variable and depends on the site and number of specimens; it has been reported above $70 \%$.

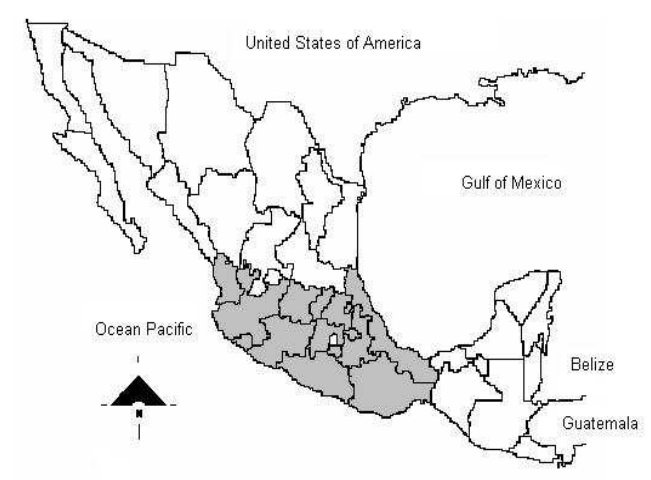

Figure 1. Geographic distribution of Triatoma barberi in the states of Colima, Guanajuato, Guerrero, Hidalgo, Jalisco, Michoacan, Morelos, Oaxaca, Puebla, Queretaro, Tlaxcala and Veracruz. Mexico.

In the state of Guerrero, a representative sampling was performed in 20 localities, which included 978 houses and 4,372 individuals: of these 132 (3\%) were positive and titers as high as 1:5500 were found in 75 persons $(1,7 \%)$. In this study, a very important finding is reported regarding seropositive children under the age of 10 years in the regions of the Costa Chica and Tierra Caliente of this state, indicating that there is an active vectorial transmission. Although it is noticeable that $33.0 \%$ of seropositivity correspond to the 45 64 age range and $56.0 \%$ to those over 65 years of age. On the other hand, only $55.0 \%$ of the studied population recognized the vector and $7.0 \%$ related it with the disease, people also commented on the vectors but could not identify the involved species (Andersson et al 1990). Other studies have found $8.5 \%$ (Biagi et al 1964), 23.4\% (Velasco \&
Guzmán 1986) and 0.1\% (Velasco et al 1992) of seroprevalence.

In the state of Michoacán, in three localities of the Tuxpan County, T. barberi was found with $37.0 \%$, $40.0 \%$ and $47: 0 \%$ of natural infection (Tay \& Biagi 1964). Another study reports in one locality a 7,2\% (12/165 individuals) seropositivity, of these $17,4 \%$ with electrocardiographic findings compatible with chagasic cardiomyopathy, aside from a $10.8 \%$ seropositivity in the open population (Tay et al 1967).

In Querétaro state, this vector has been found well adapted to the domicile and, of 202 specimens, $56.6 \%$ had natural infection; a $42.6 \%$ of seropositivity was reported with $16.0 \%$ coursing with electrocardiographic alterations compatible with the disease and $2.0 \%$ with megaesophagus (De Haro 1997). Two studies report serological findings with $0.2 \%$ for the state (Velasco et al 1992) and $26.7 \%$ for one locality (Velasco \& Bracho 1986).

We have found T. barberi in the wall at the level of the bed in deep wall fissures (which protect them from the environment and provide a dark habitat). About their behavior they are attracted by artificial light and have nocturnal activity. Our observations indicate that their time of defecation is fast and occurs during feeding, a fact that we corroborated in some bedrooms in Queretaro and Oaxaca, where no fecal traces were found on the wall but rather on mattresses.

In an epidemiological study performed in four localities of the Zacoalco de Torres County, Jalisco, the only vector found was T. barberi, collecting 281 specimens; of these 176 (62\%) were positive to $T$. cruzi. In addition, 530 persons 
were studied, seven $(1.3 \%)$ were seropositive by Indirect Hemagglutination assay, eight (15.0\%) parasitologically positive and, of these, three with symptomatology and/or electrocardiographic alterations attributed to chagasic cardiomyopathy (Tay et al 1979). Seroprevalence of 19.5\%, 16.3\%, and $13.5 \%$ were reported in three localities (Velasco \& Bracho 1986), and of $0.1 \%$ for the state (Velasco et al 1992). However, in a study undertaken in localities of Jalisco and Nayarit, $T$. barberi was found in peridomestic areas; in the author opinion, this species is a minor vector of Chagas disease in these studied localities Martínez et al 2008).

For the state of Morelos, observations made about T barberi include its nocturnal habits or its feeding in dark rooms during the day, its flight and attraction to light, its anthropophilic behavior; this species has been collected in all developmental stages in human dwellings and has been found in temperate and semitropical climates (Tay et al 1966). Twenty-five adult T. barberi with $68.0 \%$ $(17 / 25)$ of natural infection have been collected (Cortés et al 1996).

In Oaxaca, from 362 captured $T$. barberi specimens, $261(72.0 \%)$ were infected with $T$. cruzi their main feeding source were rodents and humans, it is reported as a domiciliated species and is considered responsible for the transmission of Chagas disease in the valley of Oaxaca (Zárate et al 1980). Our research group captured this vector in four localities of this state, and $9.17 \%$ seropositivity was reported. In one of these localities, near the city of Oaxaca, the seropositivity of the child population under the age of 12 years was of $21.0 \%$ (Salazar et al 1984b). In another of these localities, 50 individuals aged from 16 to 21 years were studied, $10(20.0 \%)$ presented positive serology and electrocardiographic alterations compatible with Chagas disease (Salazar et al 1989). Vidal et al 2000 found that of $21 \mathrm{~T}$. barberi specimens only one $(4.8 \%)$ was positive to $T$. cruzi infection.

In Tlaxcala, only $T$. barberi has been reported (Zárate \& Zárate 1985) and Velasco et al. 1992 registered a $0.2 \%$ seroprevalence.

In the state of Hidalgo, 1,826 houses were sampled in 13 Sanitary Jurisdictions, the only species found were T. barberi and T. dimidiata, in seven $(54.0 \%)$ of the 13 Sanitary Jurisdictions; 321 specimens were captured in $85(4.6 \%)$ houses. Eggs, nymphs, exuviae, and 192 adult specimens were collected; of these $89(46.3 \%)$ were males and $103(54.0 \%)$ females, 58 (30.0\%) specimens corresponded to T. barberi and 134 (70.0\%) to $T$. dimidiata, with $15.0 \%$ and $8.0 \%$ positive $T$. cruzi infection, respectively. A $3.0 \%$ infection risk index was obtained for the state. Since these two are intradomiciliary species, they involve the same risk factors, such as overcrowding, deficient wall, roof, floor construction, lack of water, and the presence of animals inside the houses. Construction material for the wall (adobe, reed, wood, and stone) roof (straw, palm, shingles, roof tiles, wood, and lamina), and soil floors represent higher risks of infestation with $T$. dimidiata whereas for T. barberi, stone walls are the culprits (Escorza et al 2001). These observations coincide with observations made for $T$. dimidiata in Veracruz and for T. barberi in Querétaro (Salazar et al 2005a, Salazar et al 2005b, De Haro 1997).

\section{Triatoma dimidiata (Usinger, 1944)}

This vector is widely distributed along the American continent, and has been recorded from the north of Peru to the north of Mexico. 
It has been capture in 16 states of Mexico: Campeche, Colima, Chiapas, Estado de Mexico, Guanajuato, Guerrero, Hidalgo, Jalisco, Nayarit, Oaxaca, Puebla, Quintana Roo, San Luis Potosí, Tabasco, Veracruz, and Yucatán (Salazar et al 1988, Cruz \& Pickering 2006, Lent \& Wygodzinsky 1979, Zárate \& Zárate 1985) (Figure 2). It has been reported at altitudes from sea level to 2.360 masl (Vidal et al 2000, Ramsey 2000). The female measures $24,5-35,0 \mathrm{~mm}$ and the male 24-32.0 mm (Lent \& Wygodzinsky 1979).

Triatoma dimidiata is to dwell on the floor, particularly beneath the beds and in the angle formed by the floor and the wall (Salazar et al 2005 b). It is also attracted by artificial light; it defecates at around 10 to $20 \mathrm{~min}$ after eating.

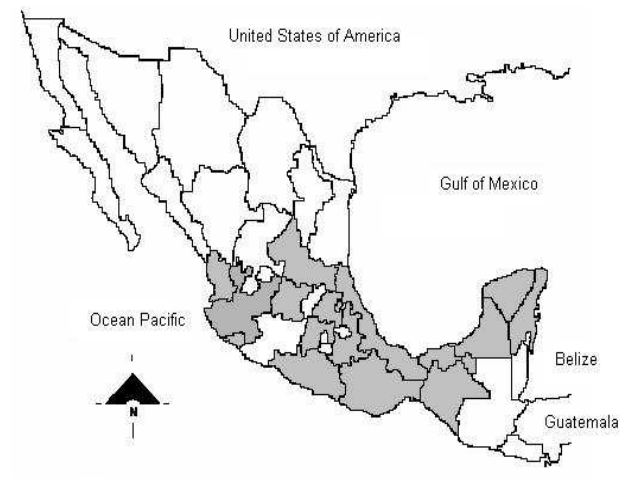

Figure 2. Map of Mexico showing the distribution of Triatoma dimidiata in the states of Campeche, Colima, Chiapas, Estado de Mexico, Guanajuato, Guerrero, Hidalgo, Jalisco, Nayarit, Oaxaca, Puebla, Quintana Roo, San Luis Potosi, Tabasco, Veracruz and Yucatan.

In Chiapas, $T$. dimidiata is among the five reported species (Zárate \& Zárate 1985). This species was found domiciliated (López-Ordoñez et al 2006). A seroprevalence between $14.0 \%$ and $28 \%$ has been reported (Goldsmith et al 1983) and Velasco et al (1992), reported $3.0 \%$ of seroprevalence, the highest in the country.

In Guanajuato, one $T$. dimidiata specimen, negative to $T$. cruzi infection, has been reported (Vidal et al 2000). The finding of only one specimen suggests the possibility that it might have been transported from another part of the country. Velasco et al (1992) reported $0.1 \%$ seroprevalence for the state.

In Guerrero, eight different species have been reported, among them $T$. dimidiata (Vidal et al 2000, Zárate \& Zárate 1985). Biagi et al (1964) reported $8.5 \%$ of seropositivity, but Velasco \& Guzman 1986, reported 23.4 and $18.8 \%$ in two localities.

A representative sampling of 20 communities with 978 houses and 4,372 individuals yielded 132 (3\%) seropositive individuals, 75 (1,7\%) were found with titers as high as 1:5500; and the author emphasizes a very important finding seropositivity in children under the age of 10 years in the Costa Chica region (Acapulco and Tierra Caliente region), indicating the presence of active transmission. It is worthwhile mentioning that $1,443(33 \%)$ individuals were aged 45-64 years and 2,448 (56\%) were older than 65 years; on the other side, only 2,405 (55\%) persons recognized the vector and only $306(7.0 \%)$ related it to the disease [25]. A $0.1 \%$ seroprevalence is reported for the state (Velasco et al 1992).

In Jalisco, T. dimidiata is one of the eight reported vectors. In a study, only one specimen was found intradomiciliated, just like T. brailovskyi, leading the authors to conclude that both are intradomiciliary species (Magallón et al 1998).

In the state of Mexico, $T$ dimidiata was found in an area neighboring the state of Morelos. In this state, a study in 380 dwellings of 100 localities in five counties was carried out; $24.0 \%$ of the localities were positive to triatomines, $53,8 \%$ were captured in the intradomestic area and $42,3 \%$ in the peridomicile, and $3,8 \%$ in both sites. $T$. 
dimidiata was captured in only one locality all negative to $T$. cruzi infection. $T$. dimidiata has been reported at altitudes between 600 and 1,600 masl in the State of Mexico (Martínez et al 2002). Seroprevalence was negative in this state (Velasco et al 1992).

In the state of Puebla, Sandoval et al (2002) collected 338 specimens of $T$. dimidiata, 62 $(18.3 \%)$ of them were females and 48 (14.2\%) males; natural T. cruzi infection was positive in 30 specimens $(8.8 \%)$. Localities with seroprevalence of $52.1 \%, 4.0 \%, 20.7 \%$ and $28.0 \%$ have been reported (Velasco \& Guzmán 1986) -27 and, in the National Seroepidemiological Survey, the prevalence for the state was negative Velasco et al (1992).

In Oaxaca, 195 specimens of $T$. dimidiata have been reported, eight $(4.1 \%)$ were positive to $T$. cruzi infection (Vidal et al 2000).

In the state of San Luis Potosí, Vidal et al (2000) found 58 specimens of $T$. dimidiata three (5.2\%) of them were positive to T. cruzi. A serological study of the indigenous population of the Huasteca Potosina revealed $10.8 \%$ seropositivity (Garrocho et al 1991) and a $0.2 \%$ seroprevalence has been reported for the state (Velasco et al 1992).

In the state of Tabasco, this vector has been reported by several authors (Salazar et al 1988, Lent \& Wygodzinsky 1979, Zárate \& Zárate 1985). Regarding seroprevalence, one survey reports 13.0\% (Sanchez 1988) and another 0.1\% for the state (Velasco et al 1992).

In the state of Veracruz, was reported Conorrhinus dimidiatus (Champion 1899) "as the probable vectors of the Chagas tripanosomiasis" (Hoffmann
1928). Vidal et al (2000) found 1,934 triatomines, 269 (14\%) were positive to T. cruzi infection.

In a study performed by our research group, (in eleven Sanitary Juridictions) 2,526 specimens of T. dimidiata were found, 2,248 (89\%) specimens collected intradomiciliary and $278(11 \%)$ in the peridomicile. This species is perfectly adapted to the intradomicile environment; we found eggs and nymphs, as well as, adults inside the domicile. The infestation, colonization, and infection indexes were $13.5 \%, 60.8 \%$ and $10.6 \%$, respectively, the ecotopes were bedrooms $(84.0 \%)$, storage rooms $(3.0 \%)$, and other sites $(13.0 \%)$; within the bedrooms, the ecotopes corresponded to wall-bed $(56.0 \%)$ bed $(39.0 \%)$ floor $(4.0 \%)$, clothes closet and window (1.0\%).

In the Sanitary Jurisdiction 2, the largest numbers of $T$. dimidiata specimens were captured with a $10.0 \%$ infection index and the highest seropositivy $(2.8 \%)$ of the state, indicating that the abundance of the vectors represents a higher risk. In the Sanitary Jurisdiction 7 of Orizaba (with an average altitude of 1.230 masl and an average temperature of $18^{\circ} \mathrm{C}$ in the center of the state), the vector was not found and the human serology was negative.

Regarding this study, we study 9,782 individuals in nine of the 11 sanitary jurisdictions, the seroprevalence ranged from zero to $2.8 \%$. In five, we found individuals below the age of 18 years old, already infected, which indicates an active transmission (Salazar et al 2005b). In another study carried out also in the state of Veracruz, only in population under 18 years of age, we found a seroprevalence between $0.4 \%$ and $5.2 \%$ in 1,544 samples studied (Salazar 2007a). Others studies report $22.1 \%$ and $0.4 \%$ for the state (Velasco \& Guzmán 1986, Velasco et al 1992). 
This vector, which was the only one found domiciliated in the State of Veracruz, was found also in the intradomestic area in the states of Hidalgo, San Luis Potosí, Puebla, and Estado de México. It is essentially sylvatic in the Yucatan Peninsula (Campeche, Yucatán, and Quintana Roo). A study performed in 115 houses of 23 localities distributed in the Peninsula found a higher abundance of $T$ dimidiata during the hot season. Their findings implied that this vector does not colonize human dwellings in the Peninsula of Yucatan. These authors also reported a $34.0 \%$ natural infection for this vector in the peninsula (Dumonteil et al 2002).

Regarding seroprevalence, Quintal et al (1975) has reported 11.2\% in Yucatán, Barrera et al 1992 found $6.12 \%$ of positive individuals in 96 blood donors, and Farfán-Ale et al (1992) found 18.0\%; Rodriguez et al (1995) in 215 donors found 5.6\% prevalence and Zavala et al (1995) reports $17.0 \%$ of cardiopathies in 36 patients (6/36). Velasco et al (1992) reported that seroprevalence was negative in Campeche and Yucatan, whereas it was $0.3 \%$ in Quintana Roo.

\section{Meccus longipennis (Usinger, 1939)}

This species is exclusive of Mexico, and is found mainly distributed in the western states of Mexico: Aguascalientes, Colima, Chihuahua, Guanajuato, Jalisco, Michoacán, Nayarit, Sinaloa, and Zacatecas (Figure 3) (Zárate \& Zárate 1985) at an altitude from 200 to 1.500 masl (Carcavallo et al 1999). The female measures 30 to $37 \mathrm{~mm}$ and the male from 29 to $34 \mathrm{~mm}$ (Lent \& Wygodzinsky 1979).

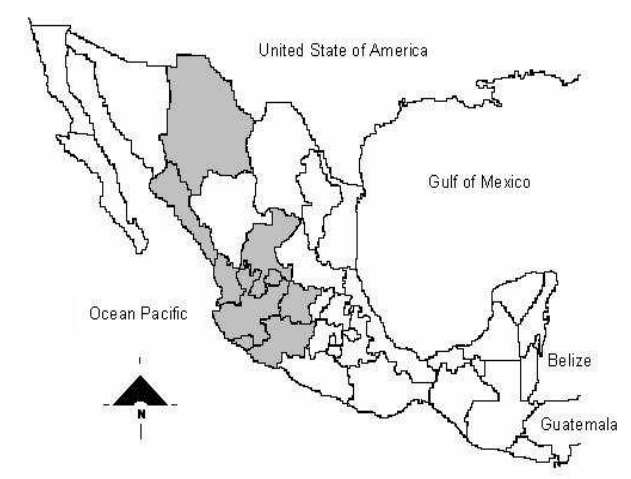

Figure 3. Distribution of Meccus longipennis in the states of Aguascalientes, Colima, Jalisco, Michoacan, Nayarit, Sinaloa, Zacatecas, Chihuahua and Guanajuato. Mexico.

Trypanosoma cruzi infection percentages by this vector vary among the different states; in Nayarit 24 insects were reported, seven (29.2\%) were infected (Vidal et al 2000). In other studies, $M$. longipennis was captured in the peridomicile (Martínez et al 2008, Magallón et al 2001, Magallón et al 2004). A natural infection of $29.3 \%$ (98/334) has been reported (Martínez et al 2001) and of $21.7 \% \quad(118 / 548)$ (Martínez 2008). Serology was of $22.0 \%$, in the counties of the center and north of the state (Flores et al 1990).

In Colima, the most recent study revealed 33.3\% $(n=42)$ of natural infection percentage for this vector (Espinoza et al 2002). Seropositivity is of $2.4 \%(n=405)$ in inhabitants of 17 communities distributed across the state (Coll et al 2004).

In Jalisco, it is reported peridomiciliated (Magallón et al 2001, Magallón et al 2004). The percentages of $M$. longipennis infected with $T$. cruzi vary from $25.0 \%$ up to $85 \%$, however, in most reports the percentage is close to $35.0 \%$, with more than 200 revised triatomines (Martínez et al 2008, Magallón et al 2001, Martínez et al 2004, Brenière et al 2004, Brenière et al 2007).

Serological studies reveal a seroprevalence of 
$0.1 \%$ (Velasco et al 1992), of $17.3 \%(n=7,178)$ in children under 14 years of age and of $16.7 \%(n=$ 42 ) in the studied inhabitants of the Zacoalco de Torres County (Lozano et al 1992). The Trypanosoma cruzi infection prevalence in the 124 counties of the state revealed a rate of $17.7 \%$ of infected people Trujillo et al (1993). In a research conducted in "Los Guerrero" village, Jalisco, (Brenière et al 2007) reports $46.0 \%$ of natural infection for this species collected in the peridomicile.

In Aguascalientes, a surveillance study, covering the completely state, reported that $100 \%(n=46)$ of the $M$. longipennis specimens was positive to $T$. cruzi infection Rubio (1993). In Guanajuato, three negative specimens have been reported (Vidal et al 2000).

In the state of Zacatecas, M. longipennis was reported as $T$. phyllosoma intermedia (Tay et al 1968), and although nymphs are reported, no data are given on their stages, with these data it is not possible to know whether domiciliation or not exists in the state. A seroprevalence of $11.9 \%$ $(n=425)$ was reported in the inhabitants of the Juchipila canyons (Cortés et al 1990).

\section{Meccus mazzottii (Usinger, 1941)}

This species is endemic and exclusive of Mexico. It has been reported in the states of Durango, Guerrero, Jalisco, Michoacán, Nayarit, and Oaxaca (Lent \& Wygodzinsky 1979, Carcavallo et al 1989) (Figure 4). In an altitude between nine and 750 masl (Vidal et al 2000, Carcavallo et al 1989, Ramsey et al 2000), the size of females is of $34.0 \mathrm{~mm}$ and that of males is $33.0 \mathrm{~mm}$ (Lent \& Wygodzinsky 1979).

Recent search have been carried out, in the states of Jalisco and Nayarit (located in the west of Mexico) (Martínez et al 2008, Martínez et al 2001) without any findings of M. mazzottii in both states.

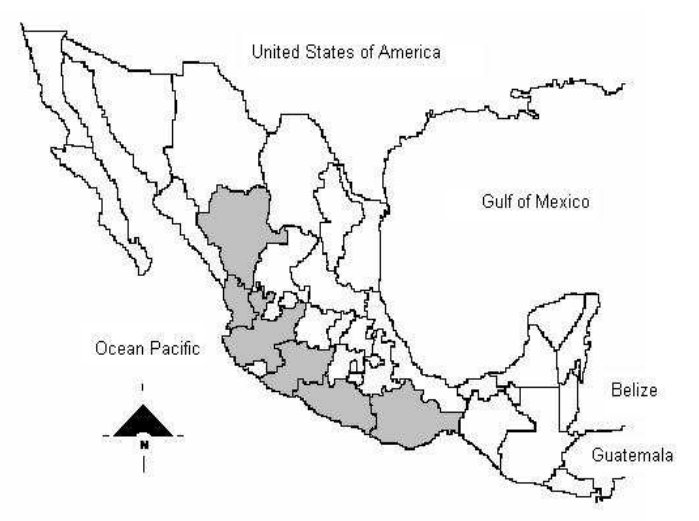

Figure 4. Map of Mexico showing the distribution of Meccus mazzottil in the states of Durango, Guerrero, Jalisco, Michoacán, Nayarit and Oaxaca.

In Jalisco, a study performed in 51 of the 124 counties reported $53.0 \%(27 / 51)$ positivity to $T$. cruzi; in general, 1,029 triatomines were collected and only four were $M$. mazzottii two of them were positive to $T$. cruzi infection (Magallón et al 1998). The Ministry of Health of the state of Jalisco reported a $T$. cruzi infection index of $27.5 \%(n=40)$ in the 124 counties of the state (Secretaria de Salud de Jalisco2005).

In the state of Oaxaca, Vidal et al (2000) found fifteen vectors, one was positive to $T$. cruzi infection. A recent study revealed a $T$. cruzi infection index of $33.9 \%$ in 28 communities. Likewise, a seroprevalence of $13.0 \%$ was recorded for the same area. Another study documents the migration of $M$. mazzottii from the coastal regions to higher zones of the state as inferred from the decreasing percentages of natural $T$. cruzi infection with increasing altitude. This species has been the predominant vector in Oaxaca according to its distribution, abundance, and infection indices; therefore, its relevance in this state is emphasized. In contrast to M. longipennis and $M$. picturatus, collected mainly in the peridomicile, 
M. mazzottii is frequently found inside human dwellings in the state (Ramsey et al 2000).

This behavior of invading houses has been facilitated by the feasibility this species seems to have of feeding from either birds or mammals, developing profitably. A recent study revealed, hat there is no difference in the time of development when this species is fed with hen blood (191.7 \pm 22.8 days) or rabbit blood $(201.9 \pm 9.7$ days $)$ (Martínez et al 2006).

\section{Meccus pallidipennis (Stål 1872)}

This vector was reported, in Oaxaca, as the first vector infected with T. cruzi in Mexico (Mazzotti 1936).

This vector has been reported in the states of Colima, Estado de México, Guanajuato, Guerrero, Jalisco, Michoacán, Morelos, Nayarit, Oaxaca, Puebla, Querétaro, Veracruz, and Zacatecas (Vidal et al 2000, Carcavallo et al 1999, Zárate \& Zárate 1985, López et al 2005) (Figure 5). It is found at altitudes from 200 to 1.580 masl. The female measures 32 to $35 \mathrm{~mm}$ and the male from 31 to 34 mm (Lent \& Wygodzinsky 1979).

In Colima Vidal et al (2000), reports one negative insect. In a study carried out at 218 homes from 16 localities, 456 triatomines were captured of which 139 belonged to $M$. pallidipennis, 95 insects were collected in the intradomicile, 36 in the peridomicile, and 8 in the sylvatic area. The dejections of 62 insects were examined to look for flagellates and 26 were positive to $T$. cruzi (42.0\%) (Espinoza et al 2002). Previous registrations of Triatominae in the state of Colima had been limited to the sylvatic area, with this study the association is demonstrate with the human housing, coinciding with another study that report these insects in the intradomicile (Bautista et al 1999). Here, also, are reported 236 nymphs, 156 were found in the intradomicile, 76 in the peridomicile, and 14 in the sylvatic area, the author do not refer to stages, which raises the doubt whether the domicile is or not colonized or whether the vectors had started to become intradomicile.

A seroprevalence study performed in 17 communities of this state detected 405 (2.4\%) seropositive inhabitants (Coll et al 2004), higher than the percentage reported in a previous study (Velasco et al 1992).

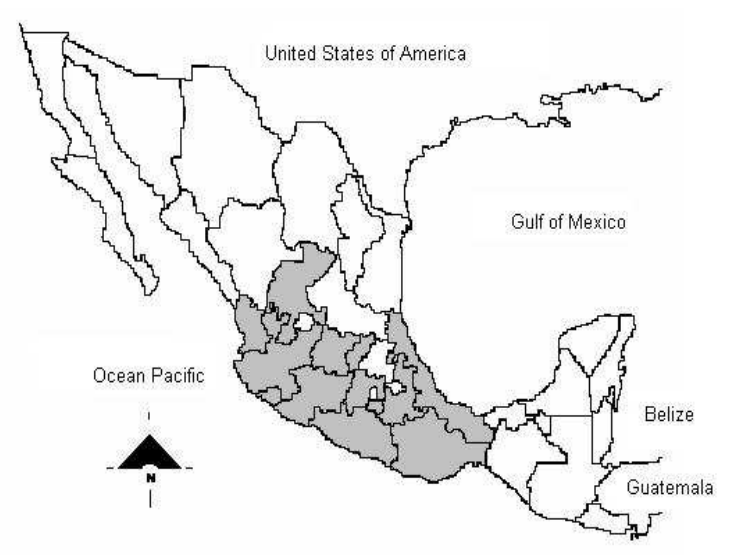

Figure 5. Map of Mexico showing the presence of Meccus pallidipennis in the states of Colima, Estado de Mexico, Guanajuato, Guerrero, Jalisco, Michoacán, Mor elos, Nayarit, Oaxaca, Puebla, Queretaro, Veracruz and Zacatecas.

In the state of Mexico, M. pallidipennis is in an area neighboring with the state of Morelos (Zárate \& Zárate 1985). In a study of 380 human dwellings in 100 localities in five counties, specimens were captured in $24.0 \%$ of the localities of which $51.4 \%$ corresponded to M. pallidipennis and $5.6 \%$ to $T$. dimidiata, both species were found at 600 to 1.600 masl. The two vectors were found intradomiciliated in a $53.8 \%$ and $42.3 \%$ in the peridomicile, and $3.8 \%$ in both locations; however, it is not specified whether the introdomicile specimens were adults or nymphs, 
$33.4 \%$ of $M$. pallidipennis were positive to $T$. cruzi infection (Martínez-Pérez et al 2002). Negative seroprevalence is reported (Velasco et al. 1992), for this state.

In Guanajuato, M. pallidipennis is reported among four other species, it was captured between 1.700 to 1.850 masl (López et al 2002, López et al 2005).

In the state of Jalisco, one study report that of 228 specimens, 164 were collected in the peridomicile and 64 intradomicile. The natural infection index is $14.0 \%$. A recent study found that of 172 specimens, 54 were adults and from these 50 belonged to this vector, 48 of them were analyzed finding $33(68.7 \%)$ positive to the parasite. These authors state that the vector is mainly peridomiciliated; it is noteworthy that its life cycle is accomplished on the stonewall fences (Magallón et al 1998, Magallón et al 2004). These observations were also reported in the state of Morelos Bautista et al (1999). Velasco et al (1992) reported $0.1 \%$ seroprevalence for this state.

In the state of Michoacán, 48 studied individuals, revealed $8.3 \%$ (4/48) with electrocardiographic alterations (Tay et al 1967). Of 22 specimens captured of this vector, $36.4 \%$ (8/22) were positive to $T$. cruzi infection (Vidal et al 2000).

In the state of Morelos, adults have been captured either intradomicile or peridomicile at broad daylight. According to Tay \& Biagi (1966), this vector was found at 1.000 to 1.800 masl and practically all developmental stages were captured in the intradomicile, with nocturnal feeding habits. In contrast, the results of Cortés et al (1996), who aiming at knowing the frequency of $T$. cruzi infected triatomines in the Cuernavaca County reports that of the 1,060 triatomines captured, 1,035 belonged to the M. pallidipennis species, and were captured around the houses, confirming their peridomestic habitat.

Of the specimens found farther away from downtown, $75.0 \%$ to $95 \%$ were infected, whereas from those captured downtown only 33.0\% were infected with $T$. cruzi. In contrast to the high infection is the finding of few metacyclic forms in the feces and a prolonged defecation pattern, arguing that these two factors make it a poor vector for T. cruzi.

In a research performed in the Sanitary Jurisdiction " 2 " in 24 studied localities, only in seven the vector was found, the distribution in the domestic area was of 41 specimens (32 adults and 9 nymphs) with $29.0 \%$ of natural infection. In the peridomestic area, 48 specimens (31 adults and 17 nymphs) with $4.0 \%$ of natural infection, and, in the sylvatic area $186,(113$ adults and 73 nymphs) were found with $20.0 \%$ of natural infection. According to the number of specimens captured, it is suggest that this species is sylvatic. Inside the domicile, only $4^{\text {th }}$ stage and up specimens were found, and the metacylogenia index was of $28.0 \%$ which is considered low (Bautista et al 1999, Cortés et al 1996). Vidal et al (2000) report four $M$. pallidipennis specimens, two positive to $T$. cruzi infection.

Seropositivity was of $11.5 \%$ in the Sanitary Jurisdiction 2 of the state (García de la Torre 1996). Seroprevalence studies reveal different percentages, such as 28.6\% Sánchez (1988) and $0.1 \%$ (Velasco et al 1992).

\section{Meccus phyllosomus (Burmeister, 1835)}

This vector has been reported only in Mexico in 
the state of Oaxaca (Galvão et al 2003, Lent \& Wygodzinsky 1979, Carcavallo et al 1999, Zárate \& Zárate 1985) (Figure 6). It has been found at an altitude of 10 to 1.200 masl Ramsey et al (2000). The female measures between 29 to $39.5 \mathrm{~mm}$ and the male between 26.5 to $38.0 \mathrm{~mm}$ (Lent \& Wygodzinsky 1979).

Even though it has been reported that six specimens of this species have been collected in the peridomicile (Magallón et al 1998), a recent search in the same study area, did not yield any captured specimens (Martínez-Ibarra et al 2008).

Vidal et al (2000) in Oaxaca reported 33 specimens, three (9.1\%) were positive to $T$. cruzi. Velasco et al (1991) reported $0.9 \%$ of seroprevalence.

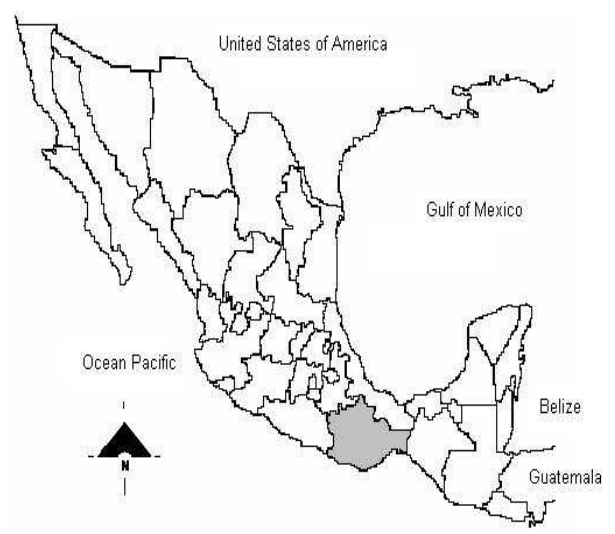

Figure 6. Geographic distribution of Meccus phyllosomus in the state of Oaxaca. Mexico

\section{Meccus picturatus (Usinger, 1939)}

This species, also exclusive in Mexico, has been reported in the states of Colima, Jalisco, Nayarit, and Oaxaca (Cruz \& Pickering 2006, Galvão et al 2003, Lent \& Wygodzinsky 1979) (Figure 7). It has been found at altitudes from 250 to 1.200 masl (Carcavallo et al 1999), and the size of the female is 32 to $33 \mathrm{~mm}$ and that of the male is 30.5 to 32.0 mm (Lent \& Wygodzinsky 1979).
In two studies performed in 2000 and 2002, this species was not detected in any of the counties of the states of Nayarit and Oaxaca (Ramsey et al 2000, Martínez-Ibarra 2006). However, Magallon et al (2001) in Carrillo Puerto, Compostela County, in the state of Nayarit, reports the capture of $M$. picturatus, two specimens were in the domestic area, both negative to $T$. cruzi infection, 23 insects in the peridomicile with 10 positive insects to $T$. cruzi, and 28 in the sylvatic area, with 10 positive insects to $T$. cruzi.

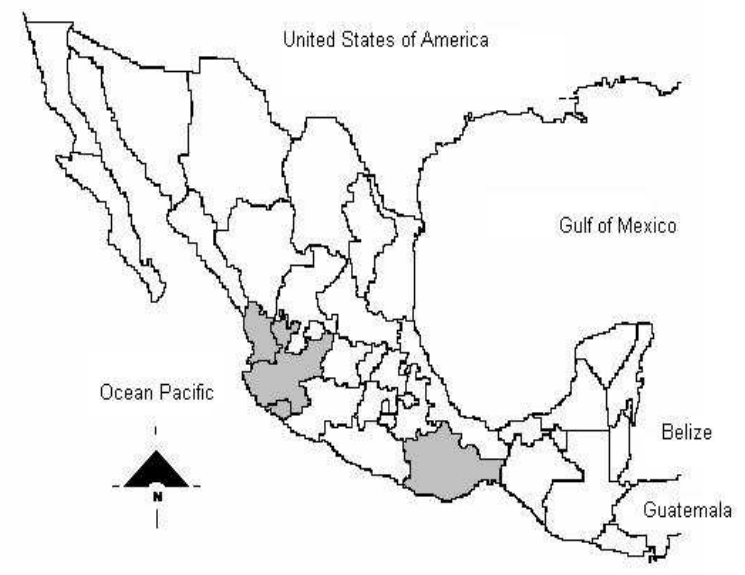

Figure 7. Meccus picturatus distribution in the states of Colima, Jalisco, Nayarit and Oaxaca. Mexico.

Vidal et al (2000) find that five (83.3\%) out of six specimens captured in Tepic were reported as positive. In relation to serology, Flores et al (1990) reported $22.0 \%$ in the revised population in counties of the center and north of the state.

In the state of Jalisco, this species is usually associated to $M$. longipennis. The reports about positivity to $T$. cruzi in M. picturatus range from zero in the Crucero de Santa María (MartínezIbarra et al 2001) to $7.4 \%(n=27)$ in the sampling of 51 counties (Magallón et al 1998), and to up to $35.4 \%(n=82)$ in Talpa de Allende (MartínezIbarra et al 2008). In the municipality of San Martin de Hidalgo, Magallón et al (2004) report the capture of 172 triatomines, of which 54 were 
adults, 50 insects were $M$. longipennis and four specimens corresponded to $M$. picturatus of this last species two were positive to $T$. cruzi infection. Serological studies show that the prevalence of Trypanosoma cruzi infection in the 124 counties of the state of Jalisco is of 17.7 per 100 inhabitants (Trujillo et al 1993). The seroprevalence was $17.3 \%(n=7,178)$, in children under 14 years old (Molina et al 2007), 16.7\% $(n=42)$ in the inhabitants of the county of Zacoalco de Torres (Lozano et al 1992), and of $2.98 \%(n=168)$ in the rural area of Teocuitatlán de Corona (MartínezIbarra et al 2008).

Several authors have found Meccus picturatus and M. longipennis predominantly in the stone walls (Magallón et al 1998, Magallón et al 2004, Martínez-Ibarra et al 2001, Espinoza et al 2002, Breniére et al 2004, Martínez-Ibarra et al 2006). Although $10 \%$ to $20 \%$ of the total collected specimens come from inside the houses, in the states of Jalisco and Nayarit, both species are found in the hen pens and in other domestic animal shelters (Martínez-Ibarra et al 2008, Magallón et al 2004).

None of the two species seems to be influenced in its development by the type of blood source (bird or mammal). The life cycle did not vary significantly when $M$. longipennis was fed with hen blood $(229.7 \pm 418)$ or rat blood $(259.8 \pm 287)$ and $M$. picturatus was fed with hen blood (196.8 \pm 15.8) or rabbit blood $(189.5 \pm 22.9)$ (MartínezIbarra et al 2003, Martínez-Ibarra et al 2004).

\section{Triatoma gerstaeckeri (Stål, 1859)}

This vector has been reported in Chihuahua, Coahuila, Hidalgo, Nuevo León, San Luis Potosí, Sinaloa, Tamaulipas, Veracruz, and Zacatecas (Salazar et al 1988, Vidal et a. 2000, Lent \&
Wygodzinsky 1979, Zárate \& Zárate 1985, Martínez-Ibarra et al 1992, Galaviz et al 1992), (Figure 8). The female measures 24 to $28.5 \mathrm{~mm}$ and the male 23 to $26 \mathrm{~mm}$ (Lent \& Wygodzinsky 1979). In Chihuahua, T. gerstaeckeri has been collected between 940 to 1.380 masl, 27 adult specimens were captured in the peridomicile in a research conducted in three counties, three insects were positive to T. cruzi infection (11.1\%) (Díaz et al 2007).

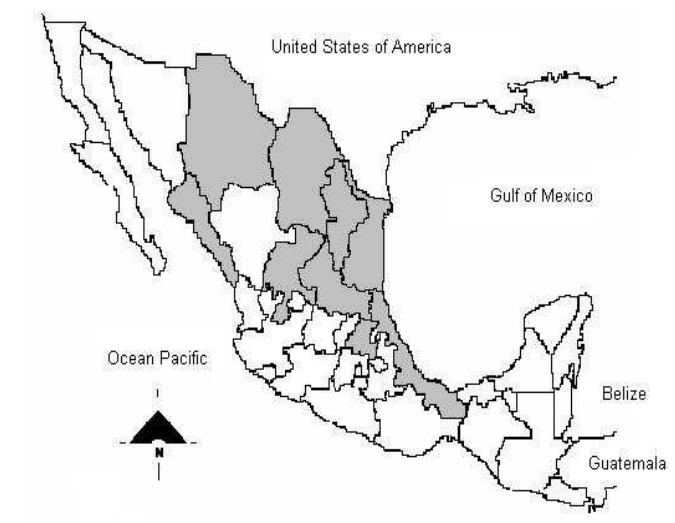

Figure 8. Map of Mexico showing the distribution of Triatoma gerstaeckeri in the states of Chiluahua, Coahuila, Hidalgo, Nuevo Leon, San Luis Potosi, Sinaloa, Tamaulipas, Veracruz and Zacatecas.

In the states of Nuevo León and Tamaulipas, $T$. gerstaeckeri is mostly found inside the domicile in its adult stage but, like other species of the Meccus genus, is found in the peridomicile. Seroprevalence was of $0.2 \%$ for Nuevo León and of $0.1 \%$ for Tamaulipas. For Chihuahua and Coahuila, the seroprevalence was of $0.1 \%$ (Velasco et al 1992). Vidal et al (2000) report one T. gerstaeckeri specimen negative to $T$. cruzi infection in the state of Veracruz. In the state of Hidalgo five insects have been found between 860 to 960 masl all negative to $T$. cruzi infection. In the locality El Abra in the state of Tamaulipas we collected three adults that were negative; the villagers commented having seen them in the palm trees (unpublished data). 


\section{Triatoma mexicana (Herrich-Schaeffer, 1848)}

This vector has been reported by several authors (Vidal et al 2000, Salazar et al 2007b, Zárate \& Zárate 1985, López et al 2005) in an area circumscribed to the center and east of the country (Figure 9). It has been found at an altitude from 1.200 to 1.880 masl (Salazar et al 2007b). Lent \& Wygodzinsky (1979) reported a male that measured 25 to $26 \mathrm{~mm}$.

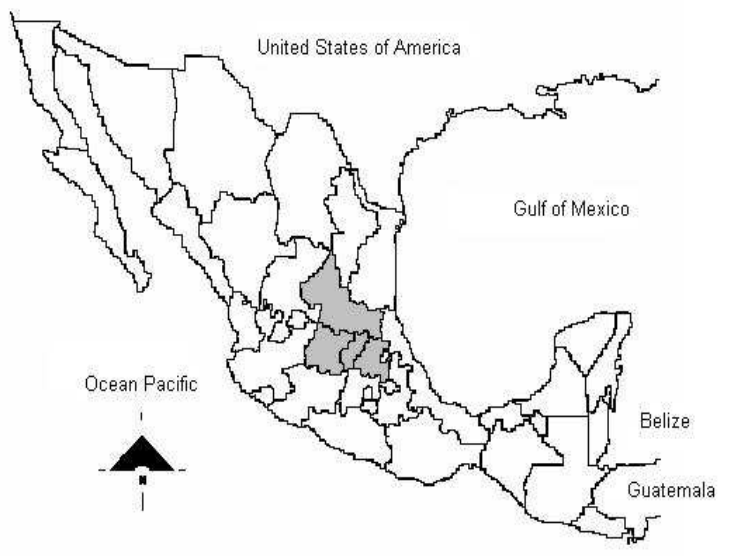

Figure 9. Distribution of Triatoma mexicana in the states of Guanajuato, Hidalgo, Queretaro and San Luis Potosi. Mexico.

In the state of San Luis Potosí, 63 specimens of $T$. mexicana were captured; all were negative to $T$. cruzi infection (Vidal et al 2000).

In a survey carried out in Guanajuato, we captured 165 specimens, the vector was found in six localities, and the locality with less altitude showed the highest infestation index, it is important to mention that its biological cycle occurs underneath the stonewalls. The natural infection index was of $3.0 \%(5 / 165) ; 14$ were captured in the intradomicile and one was positive to $T$. cruzi infection; 151 were captured in the peridomicile and four were positive to $T$. cruzi infection Salazar et al 2007a).

In the state of Hidalgo, from the 27 captured specimens, one, (3.7\%) was positive to $T$. cruzi (Vidal et al 2000). Velasco et al. 1992 report 1.5\% of seroprevalence.

\section{Triatoma rubida (Uhler, 1894)}

This vector is reported in the states of Baja California, Baja California Sur, Chihuahua, Guerrero, Nayarit, Sinaloa, Sonora, and Veracruz (Figure 10). It is suggested that its presence in the latter state is due to having been transported by humans from the north. It is found at an altitude of 200 to 1.800 masl. The female measures $19.5-23.0$ $\mathrm{mm}$ and the male 15.5-20.0 $\mathrm{mm}$ (Lent \& Wygodzinsky 1979).

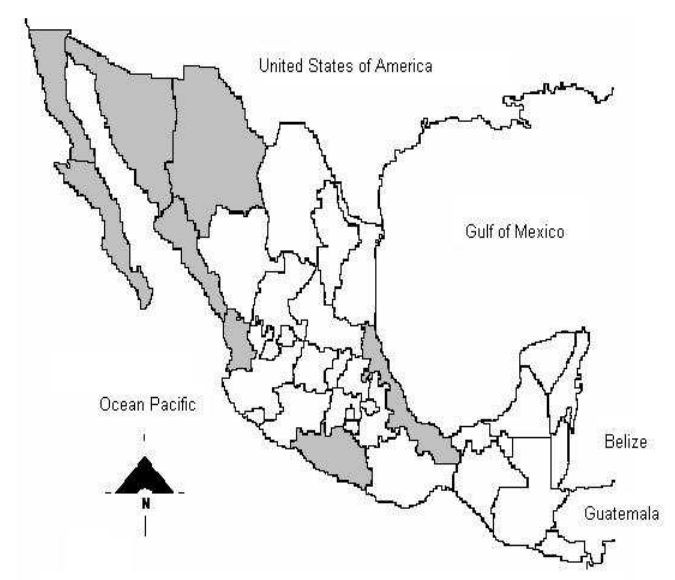

Figure 10. Geogaphic distribution of Triatoma rubida in the states of Baja Califomia, Baja California Sur, Chihuahua, Guerrero, Nayarit, Sonora, Sinal oa and Veracruz. Mexico.

In Guaymas, Sonora state (north of the country), this species is reported with sylvatic habits (Palencia \& Julia 1960). However, another author has found, in the same place nymphs in the 2 nd to 5 th instars inside human housings, reflecting its adaptation to the domicile Paredes et al (2001), fostered by the invasion of its environment with the risk of becoming intradomiciliary.

Three specimens of $T$. rubida have been reported negative to T. cruzi infection (Vidal et al 2000). Licón et al (2007) captured two vectors in Manuel Ojinaga County in Chihuahua, one was positive to T. cruzi infection. Seroprevalence was zero for Sonora and of $0.1 \%$ for Sinaloa (Velasco et al 
1992). We believe that this vector is a potential risk due to its transition in becoming intradomiciliated.

\section{Dipetalogaster maxima (Usinger, 1939)}

This species is locate only in the state of Baja California Sur, from the city of La Paz to Los Cabos (Figure 11); this is the largest size vector of Chagas disease, adult females and males can measure 41-42 and 33-35 mm respectively (Lent \& Wygodzinsky 1979). Dipetologaster maxima has a wild life cycle, but it has been observed in the last years to be in a transition and adaptation process to the human housing. We have observed females in sylvatic conditions measuring up to 47 $\mathrm{mm}$, besides this vector has a very large gastric space where it can store large amounts of blood to survive during prolonged fasting periods in semidesertic areas. It has a marked predilection to live amid stones, which has granted it the name of "chinche piedrera" (stoned bug). It is collect at an altitude of 0 to 200 masl (Jiménez \& Palacios 1999).

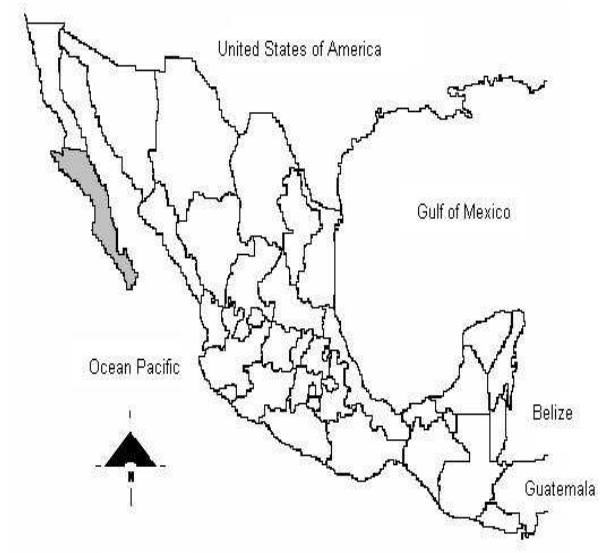

Figure 11. Map of Mexico showing the distribution of Dipetalogaster maxima in the state of Baja California Sur.

Cannibalism is observed in this species, eating up to four in a chain, from which it has been inferred that this mechanism could increase the natural infection for this vector. Besides this vector depicts a very aggressive behavior, if a human is standing in front of a pile of stones, this triatomine, in its different developmental stages, leaves its hideout at bright daylight to feed. In recent years, some of the persons bitten by this vector have had to be hospitalized due to the allergic reaction that can even lead to anaphylactic shock (comments made by the population); this is probably due to the amount of allergens in their saliva. This triatomine, similarly to T. rubida, was consider strictly sylvatic, as they had been only found occasionally in rural dwellings of the Los Cabos regions in Baja California Sur (Lent \& Wygodzinsky 1979). The highest density, as observed for other vector species, occurs during high temperatures. It has been describe to be adapted to the domicile, where it dwells on floors and walls of the houses located on the slopes of the hills. It has also been reported that in the houses away from the hills (natural ecotope), only adults have been found (Mariden et al 1979). Natural infection has been reported to be of 5.0\% (6/110X100) [86] and 7.0\% (18/245X100) (Jiménez et al 2003). The seroprevalence of the region is $0.3 \%$ (Velasco et al 1992).

\section{Panstrongylus rufotuberculatus (Champion, 1899)}

This species has been reported in the states of Campeche, Chiapas, and Veracruz (Salazar et al 1988) (Figure 12), between 50 and 630 masl. The female measures 25-28 mm and the male 24-27 mm (Lent \& Wygodzinsky 1979). 


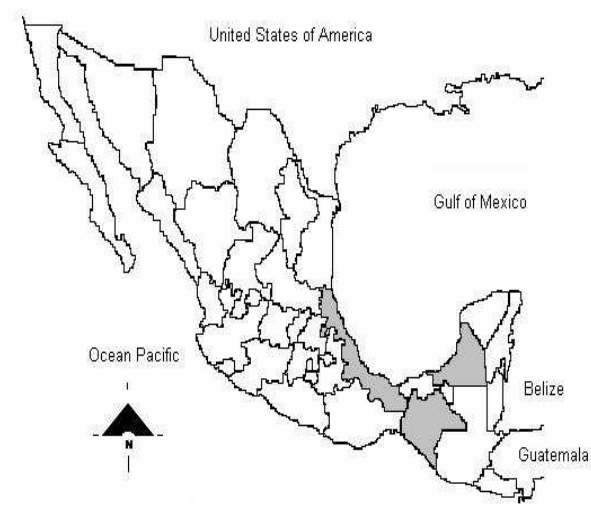

Figure 12. Map of Mexico showing the presence of Panstrongylus rufotuberculatus in the states of Campeche, Chiapas, and Veracruz.

In the wild areas in the south of Veracruz, some adults have been collected in the biological station of the Tuxtla region, and in the state of Chiapas in Bonampak (Vidal et al 2000, Zárate \& Zárate 1985 ) reports it associated to housing (one specimen), this specimen was negative to T. cruzi infection. Because it is mainly sylvatic, we believe that its risk in transmission must be very limited.

\section{Rhodnius prolixus (Stål, 1859)}

This species has been reported in the states of Chiapas and Oaxaca (Figure 13) between 640 and $660 \mathrm{~m}$ altitude. The female measures 19.5-21.5 $\mathrm{mm}$ and the male $17.5-20.0 \mathrm{~mm}$ (Lent \& Wygodzinsky 1979).

This vector was captured in Oaxaca and in the neighboring region with Guerrero (Zárate \& Zárate 1985). Its intentioned search has only brought about two specimens in two localities and one was positive to T. cruzi (Ramsey et al 2000). It is believed that its scarce distribution is due to the frequent DDT sprayings in these malaria vector regions.

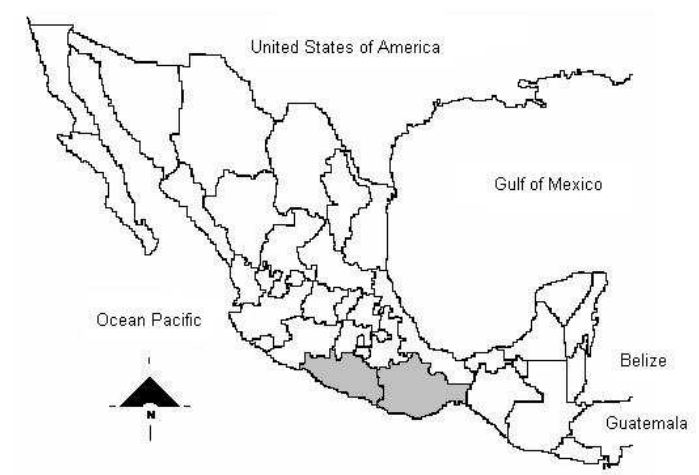

Figure 13. Distribution of Rhodnius prolixus in the states of Chiapas and Oaxaca. Mexico

\section{Discussion}

In Mexico, the behavior of the vectors is markedly different among those having a domiciliated, peridomiciliated, or sylvatic life cycle. We propose the term of "visiting vectors" for those having a peridomiciliated cycle, since they colonize the peridomicile and only enter the domicile for feeding; adults or last stage nymphs are the ones collected intradomicile and rarely are first to third instars collected.

It is also noteworthy that there is a larger number of visiting vectors species than intradomiciliated ones, being the former harder to control, since insecticides are applied on interior and exterior walls of the houses, not covering the whole peridomicile area (limiting stone-walls, wood piles, storage rooms, pens, and other constructions).

Due to the behavior of the visiting vectors, specifically M pallidipennis in Morelos, it is clear that Chagas disease is not exclusively related to poverty, as in this zone most of the housings do not present the characteristics nor the risk materials commonly associated to triatomine 
infestation.

On the other hand in our country these vectors are not constrained to tropical and subtropical areas but are also found at altitudes above 1.800 masl as is the case of Triatoma barberi which is considered as one of the most important vectors of the disease.

Among the peridomiciliated visiting vectors $M$. longipennis and $M$ pallidipennis, in that order, could be considered the most important ones. It can be said that while $T$ dimidiata is the one of the highest risk in the central part of the country towards the Gulf of Mexico, M. longipennis poses the same risk but towards the Pacific.

It is worthwhile mentioning that Dipetalogaster maxima and Triatoma rubida are currently being caught inside human dwellings, indicating that they are in the process of adapting to the domicile, whereas the remainder species of visiting vectors have not done so, despite having practically the same conditions for it.

It is very important to point out that the Seroepidemiology of Chagas disease in the Mexican survey was performed with sera from blood banks located in urban areas and this introduces a bias to the results since the vectors and transmission occur in rural areas (Velasco et al 1992). The most reliable serology results are those obtained from serological assays performed in the corresponding rural areas It is necessary to perform more studies in rural areas to gain a better insight of the actual situation; however, this review provides a panorama of the severe problem faced in Mexico regarding this disease.

We know that, at least in one locality of the rural area of all the states of Mexico, there are different vectors able to induce transmission of the disease. From this review, it can be observed that the vectors with the highest infection index associated to high serology values are found in the center towards the south of the country. Hence, this whole area, particularly the rural one can be considered of high risk. The vectors found in this area are $T$ barberi in the high plateau and $T$ dimidiata preferably towards the Caribbean and the Gulf of Mexico (intradomiciliated species) and the visiting vectors of the Meccus genus towards the Pacific.

It is interesting to note that $M$ pallidipennis is the only vector that can be found in broad day light and is not attracted by artificial light, as are all other vectors.

The fact that numerous vectors are involved in the transmission of Chagas disease gets even more complicated by the existence of hybrids of $M$ pallidipennis with $M$. longipennis and of $M$. picturatus with $M$ pallidipennis found in the west of the country (Martínez-Ibarra et al 2005). Recently, we found in the east a probable hybrid of $T$ dimidiata and $T$ mexicana with intradomiciliated habits, which is currently being subjected to molecular studies.

Control of the disease from a vectorial point of view must be based on education for health, the inhabitants particularly those of rural areas must be aware of the vector and the implications of its cohabiting inside the house recommending cleanliness as a pivotal point.

The use of insecticides for the intradomiciliated species, which has yielded successful results as observed in the study performed in Veracruz (Rojas et al 2004). For the visiting vectors, the use 
of insecticides does not have the same effect, as there is little contact with them. Studies are being made on the action of paints combined with insecticides in the state of Mexico where $M$ pallidipennis (visiting vector) is found and apparently the results are quite favorable (personal communications).

Regarding improvements of housing conditions, we believe that the use of limestone in the Peninsula of Yucatan has been instrumental in the vectors not becoming intradomiciliated, hence, the use of lime on the walls could be an action against $T$ dimidiata, as well as a cemented floor (program in the state of Veracruz) and the use of limestone blocks for the walls in the areas where $T$ barberi is found, as it has been observed in a town of the state of Queretaro, this triatomine does not establish on this type of construction. On the other hand, where visiting vector species are found it is proposed to cement the base of the stonewalls the use of mosquito nets on doors and windows to avoid entrance of vectors attracted by the artificial light and the use of bed nets impregnated with pyrethroid insecticides.

\section{Acknowledgments}

We thank to the grants received in different years by Special Programme for Research and Technical Training in Tropical Diseases Grants 970854 and A10253 (TDR/OPS/WHO); Programa de Apoyo a Proyectos de Investigacion e Innovacion Tecnologica grant IN 205305 (PAPIIT/DGAPA/UNAM/MEXICO); Programa Mesoamericano de Intercambio Académico 20022005 (ANUIES-CSUCA).

\section{Cited references}

Andersson N, Morales A, Nava E, Martínez E, Rodríguez I, et al. Trypanosoma cruzi infection in the Mexican state of Guerrero: seroepidemiological (ELISA) survey of 20 communities. Am J Trop Med Hyg. 1990; 93: 341-6.

Barrera MA, Guzmán ES, Rodríguez ME, Zavala JE. Estudio piloto para la detección de anticuerpos contra Trypanosoma cruzi en un grupo de donadores de sangre del estado de Yucatán. Rev Biomed. 1992;2:15-9.

Bautista NL, García-de la Torre GS, de HaroArteaga I, Salazar-Schettino PM. Importance of Triatoma pallidipennis (Hemiptera: Reduviidae) as a Vector Trypanosoma cruzi (Kinetoplastida: Trypanosomatidae) in the State of Morelos Mexico and posible ecotopes. J Med Entomol. 1999; 36:233-35.

Biagi F, Tay-Zavala J, Guzmán C, Fong F. Tetitlán Guerrero Foco endémico de enfermedad de Chagas. Revista de la Facultad de Medicina UNAM México. 1964; 6: 625-31.

Brenière SF, Bosseno MF, Magallón E, Castillo E, Soto M. Peridomestic colonization of Triatoma longipennis (Hemiptera Reduviidae) and Triatoma barberi (Hemiptera Reduviidae) in a rural community with active transmission of Trypanosoma cruzi in Jalisco state Mexico. Acta Tropica. 2007;101:249-57.

Brenière SF, Pietrokovsky S, Magallón-Gastélum E, Bosseno MF, Soto MM. Feeding patterns of Triatoma longipennis Usinger (Hemiptera: Reduviidae) in peridomestic habitats of a rural community in Jalisco state Mexico. J Med Entomol. 2004;41:1015-20.

Carcavallo RU, Curto de Casas I, Sherlock I, Galindez-Girón I, Jurberg J, et al. Geographical distribution and alti-latitudinal dispersion. In: 
Carcavallo RU, Galíndez-Girón I, Jurberg J, Lent $\mathrm{H}$ eds (1989) Atlas of Chagas disease vectors in the Americas. 2nd edition. Rio de Janeiro: Editora Fiocruz 1999. Vol.3: 749-792.

Coll-Cárdenas RJ, Espinoza-Gómez $F$, Maldonado-Rodríguez A, Reyes-López PA, Huerta-Viera M, et al. Active transmission of Chagas disease in Colima Mexico. Mem Inst Oswaldo Cruz. 2004;99:363-8.

Cortés-Jiménez M, Nogueda-Torres B, AlejandreAguilar R, Isita L, Ramírez E. Frecuency of Triatomines Infected with Trypanosoma cruzi Collected in Cuernavaca City Morelos México. Revista Latinoamericana de Microbiología. 1996; 38: 115-9.

Cortés-Ramírez JM, Del Río A, de la TorreMurillo A, Cabral-Soto J, Domínguez F, et al. Estudio preliminar sobre la enfermedad de Chagas en Zacatecas. In II Reun Nal Enf Chagas Tepic Nayarit; 1990.

Cortés JM, Velasco-Castrejón O, Labastida MH, Melchor AH, Duarte N, et al. La enfermedad de Chagas en Santiago Yosotiche Oaxaca México. Salud Pública de México. 1985; 27: 60-5.

Cruz-Reyes A, Pickering-López JM. Chagas disease in Mexico: and analysis of geographical distribution during the past 76 years. Mem Inst Oswaldo Cruz. 2006;101:34554.

De Haro-Arteaga I. Enfermedad de Chagas en una comunidad del altiplano mexicano. Tesis de doctorado. Universidad Nacional Autónoma de México, México, Distrito Federal, México 1997; 101 pp.

Díaz B, Banda A, Valdez E, Varela A, Royo A, et al. Presencia de triatominos y su asociación con Trypanosoma cruzi en el Desierto de Chihuahua. Revista Médico Científica Facultad de Medicina del Siglo XXI en Ciencia y Arte. 2007; 1:11-16.

Diotaiuti L, Faria-Filho OF, Carneiro FC, Dias JC, Pires HHR, et al. Aspectos operacionais do controle do Triatoma brasiliensis. Cad Saúde Pública. 2000; 16(Suppl 2): 61-7.

Dumonteil E, Gourbiére S, Barrera PM, Rodríguez FE, Ruíz PH, et al. Geographic distribution of Triatoma dimidiata and transmission dynamics of Trypanosoma cruzi in the Yucatán Peninsula of Mexico. Am J Trop Med Hyg. 2002; 67:176-83.

Escorza A, Salazar-Schettino PM, Cabrera M, Gómez J, Becerril MA. Triatominos Hematófagos transmisores de T. cruzi en el estado de Hidalgo. Gaceta Regional del Sistema de Investigación Ignacio Zaragoza SEP-CONACYT II. 2001; 15: 5-7.

Espinoza-Gómez F, Maldonado-Rodríguez A, Coll-Cárdenas R, Hernández-Suárez CM, Fernández-Salas I. Presence of Triatominae (Hemiptera: Reduviidae) and risk of transmission of Chagas disease in Colima México. Mem Inst Oswaldo Cruz. 2002; 97:2530.

Farfán-Ale JA, Loroño MA, Flores LF, Rosado EP, Arjona AI. Prevalencia de anticuerpos contra Toxoplasma gondii y Trypanosoma cruzi en el estado de Yucatán, Mexico. Rev Biomed. 1992;3:8-12.

Flores LM, De la Torre A, Vivanco N, Vergara S, Ochoa S. Enfermedad de Chagas en la zona norte y centro del estado de Nayarit. II Reun Nal Enf Chagas Tepic, Nayarit, Mexico. 1990.

Galaviz-Silva L, Ramírez E, Vázquez V. Histotropismo y patogenicidad de Trypanosoma cruzi en ratón albino (NHI) aislado de triatominos en Nuevo León, México. Bol Chil Parasitol. 1992; 47:3-10. 
Galvão C, Carcavallo R, Da Silva Rocha D, Jurberg J. A checklist of the current valid species of the subfamily Triatominae Jeannel 1919 (Hemiptera Reduviidae) and their geographical distribution with nomenclatural and taxonomic notes. Zootaxa. 2003; 202: 136.

Goldsmith RS, Zárate RJ, Zárate LG, Kagan IG, Jacobson LB, et al. Estudios Clínicos y Epidemiológicos de la Enfermedad de Chagas en Oaxaca México y un estudio complementario de siete años: 1 Cerro del Aire. Bol Of Sanit Panam. 1986;100: 145-66.

Goldsmith RS, Ortega M, Zárate RJ, Zárate LG, Beltrán F. Seroepidemiologic surveys for Chagas disease in Chiapas México. Archivos de Investigación Médica. 1983;14:43-50.

Goldsmith RS, Kagan IG, Reyes-González MA, Cedeño-Ferreira MA: Estudios Seroepidemiológicos Realizados en Oaxaca Mexico 1 Encuesta de anticuerpos parasitarios mediante la prueba de hemaglutinación indirecta. Bol Ofna Sanit Panamer. 1971; 69: 500-17.

García-de la Torre GS. Tripanosomiasis americana en el estado de Morelos, [Tesis de Maestría]. Universidad Nacional Autónoma de México, Distrito Federal, México, 1996. 211 pp.

Garrocho SC, Sánchez MB, Ladd WJ. Anticuerpos contra la Enfermedad de Chagas en la Huasteca Potosina. Rev Méd Fac Med Universidad Autónoma de San Luis Potosí. 1991;1:44-8.

Hoffmann C. Nota acerca de un probable transmisor de la tripanosomiasis humana en el estado de Veracruz. Revista Mexicana de Biología. 1928;8:12-8.

Jiménez ML, Llina J, Palacios C. Infection rates in Dipetalogaster maximus (Reduviidae: Triatominae) by Trypanosoma cruzi in the
Cape Region, Baja California Sur, Mexico. J Med Entomol. 2003;40:18-21.

Jiménez ML, Palacios C. Incidencia de la chinche piedrera (Dipetalogaster maximus) (Hemiptera: Heteroptera: Reduviidae) vector de Trypanosoma cruzi en zonas urbanas de La Paz Baja California Sur México. Ann del Instituto de Biología UNAM Serie Zoología. 1999;70:215-21.

Lent $\mathrm{H}$, Wygodzinsky $\mathrm{P}$. Revision of the Triatominae (Hemiptera: Reduviidae) and their Significance as vectors of Chagas disease. Bull Am Mus Nat Hist. 1979; 163:125-520.

Licón A, Arzaga DR, Ponce de León P, Tapia AL, Holguín H, Holguín M. Presencia de Triatominos y su infección por Trypanosoma cruzi en 3 Municipios del Estado de Chihuahua Norte de México. Revista Médico Científica Facultad de Medicina del Siglo XXI en Ciencia y Arte. 2007;1:13-17.

López-Cárdenas J, González-Bravo FE, SalazarSchettino PM, Gallaga-Solórzano JC, RamírezBarba E, et al. Fine-Scale predictions of distributions of Chagas Disease vectors in the state of Guanajuato, Mexico. J Med Entomol. 2005;42:1068-81.

López-Cárdenas J, González-Bravo FE, SalazarSchettino PM. Distribución Espacial de Vectores de la Enfermedad de Chagas en el Estado de Guanajuato1998-2000. Acta Univ Guanajuato. 2002;12: 64-9.

López-Ordóñez T, González-Ceron L, TorresEstrada JL, Salazar-Schettino PM, DanisLozano R. Actual status of the Chagas disease seroprevalence and triatomine species in a foothill region of Chiapas, Mexico. 11th International Congress of Parasitology; 2006, Glasgow, Scotland, p. 142.

Lozano-Kasten F, Hernández R, Trujillo F. Infección por $\mathrm{T}$. cruzi en la población infantil 
residente del estado de Jalisco México. III Reun Nal Enf Chagas México D. F. 1992.

Magallón-Gastélum E, Lozano-Kasten FJ, Bosseno MF, Cárdenas-Contreras R, Ouaissi A, et al. Colonization of Rock Pile Boundary Walls in Fields by Sylvatic Triatomines (Hemiptera: Reduviidae) in Jalisco State Mexico. J Med Entomol. 2004; 41: 484-8.

Magallón-Gastélum E, Lozano-Kasten F, FloresPérez A, Bosseno MF, Brenière SF. Sylvatic triatominae of the Phyllosoma Complex (Hemiptera: Reduviidae) around the community of Carrillo Puerto Nayarit Mexico. J Med Entomol. 2001;38: 638-40.

Magallón-Gastélum E, Magdaleno-Peñaloza NC, Kaatthain-Duchateau G, Trujillo-Contreras F, Lozano-Kasten F. Distribución de los vectores de la enfermedad de Chagas (Hemiptera: Reduviidae: Triatominae) en el estado de Jalisco México. Rev Biomed. 1998;9:151-7.

Mariden PD, Cuba C, Alvarenga NJ, Barreto AC. Dipetalogaster maxima (Reduviidae: Triatominae). Rev Inst Med Trop de Sao Paulo. 1979;21:202-6.

Martínez-Ibarra JA, Grant Y, Morales ZY, Haro S, Ventura LV, et al. Importance of species of Triatominae (Heteroptera: Reduviidae) in risk of transmission of Trypanosoma cruzi in western Mexico. J Med Entomol. 2008; 45: 476-82.

Martínez-Ibarra JA, Salazar-Schettino PM, Trujillo-Contreras F, Cabrera-Bravo M, Solorio-Cibrián $\mathrm{M}$, et al. Chagas disease in a rural area of western Mexico: epidemiological and entomological evidences. Proceedings of the Eleven International Congress of Parasitology, Glasgow, Scotland; 2006 Agosto 483-486.

Martínez-Ibarra JA, Alejandre-Aguilar R, TorresMorales A, Trujillo-García J, Nogueda-Torres
B, Trujillo-Contreras F. Biology of three species of the Meccus phyllosomus complex (Hemiptera: Reduviidae: Triatominae) fed on blood of hens and rabbits. Mem Inst Oswaldo Cruz. 2006; 101:787-94.

Martínez-Ibarra JA, Morales-Corona Z, MorenoRuiz M, del Riego-Ruiz R, Mundo-Barajas M. Híbridos naturales y fértiles entre especies del complejo Meccus phyllosomus (Hemiptera: Reduviidae) en Jalisco Mexico. Proceedings 40th Congreso Nacional de Entomología, Tapachula, Chiapas, México: 2005:734-738.

Martínez-Ibarra JA, Grant-Guillén Y, NoguedaTorres B, Trujillo-Contreras F. Influence of the blood meal source on the biology of Meccus longipennis Usinger 1939 (Hemiptera: Reduviidae) under laboratory conditions. J Am Mosq Cont Assoc. 2004; 20:328-30.

Martínez-Ibarra JA, Novelo-López M, HernándezRobles M, Grant-Guillén Y. Influence of the Blood Meal Source on the Biology of Meccus picturatus Usinger 1939 (Hemiptera: Reduviidae: Triatominae) under Laboratory Conditions. Mem Inst Oswaldo Cruz. 2003; 98:227-32.

Martínez-Ibarra JA, Bárcenas-Ortega NM, Nogueda-Torres B, Alejandre-Aguilar R, Rodríguez ML. Role of Two Triatoma (Hemiptera: Reduviidae: Triatominae) Species in the Transmission of Trypanosoma cruzi (Kinetoplastida: Trypanosomatidae) to Man in the West Coast of Mexico. Mem Inst Oswaldo Cruz. 2001; 96:141-4.

Martínez-Ibarra JA, Galavíz L, Lara C, Trujillo JC. Distribución de los Triatominos asociados al domicilio humano en el Municipio de General Teran Nuevo León México. Southwestern Entomologist. 1992;17:261-5.

Martínez-Pérez MA, Medina I, Alanís S, Vences A, Rojo I. Nivel de Infestación por triatominos 
e índice de infección natural de Trypanosoma cruzi prevaleciente en los municipios de Tejupilco Amatepec Tlatlaya San Simón de Guerrero y Temascaltepec Estado de México. Gaceta Médica Secretaría de Salud del Estado de México. 2002; Nueva Época Año2 eneromarzo.

Mazzotti L. Dos casos de Enfermedad de Chagas en el estado de Oaxaca Gaceta Médica de México. 1940; 70: 417-20.

Mazzotti L. Investigación sobre la existencia de la enfermedad de Chagas en el país: Demostración de los tripanosomas en los reduvídeos transmisores. Medicina Revista Mexicana. 1936; 16(282): 584-5.

Molina-Garza ZJ, Rosales J, Galaviz L, MolinaGarza D. Prevalencia de Trypanosona cruzi en triatominos silvestres de Nuevo León México. Salud Pública de México. 2007; 49:37-44.

Palencia LK, Julia J. Triatomas transmisores de tripanosomiasis en Guaymas Sonora México. Revista de la Facultad de Medicina UNAM. 1960;2:493-8.

Paredes EA, Valdéz-Miranda J, Nogueda-Torres B, Alejandre-Aguilar R, Canett-Romero R. Vectorial importance of triatominae bugs (hemiptera: reduviidae) in Guaymas Mexico. Rev Latinoam Microbiol. 2001;43:119-22.

Quintal R, Zavala J, Rodríguez M. La enfermedad de Chagas en el estado de Yucatán México. Rev Invest Clín. 1975; 27:255-8.

Ramsey JM, Ordoñez R, Cruz-Celis A, Alvear $\mathrm{AL}$, Chavez V, et al. Distribution of domestic Triatominae and stratification of Chagas Disease transmission in Oaxaca Mexico. Medical and Veterinary Entomology. 2000; 14: 19-30.

Rodríguez ME, Zavala J, Barrera MA, Guzmán E, Ramírez MJ, et al. Riesgo de transmisión de la enfermedad de Chagas por donantes de sangre. Rev Biomed. 1995;6:70-5.

Rojas-Wastavino G, Cabrera-Bravo M, García-de la Torre G, Vences-Blanco MO, RuízHernández A, et al. Insecticide and Community Interventions to control Triatoma dimidiata in localities of the State of Veracruz Mexico. Mem Inst Oswaldo Cruz 99. 2004;433-7.

Rubio-Morán R. Estudio de la subfamilia Triatominae (Hemiptera: Reduviidae) en el estado de Aguascalientes. México: Talleres gráficos del gobierno del estado de Aguascalientes; 1993.

Salazar-Schettino PM, Rosales-Piña J, RojasWastavino G, Cabrera-Bravo M, VencesBlanco MO, et al. Triatoma mexicana (Hemiptera: Reduviidae) in Guanajuato México: house infestation and seasonal variation. Mem Inst Oswaldo Cruz. 2007b;102:803-7.

Salazar- Schettino PM, Rojas-Wastavino G, Bucio-Torres M, Cabrera-Bravo M, García de la Torre G, Ruiz-Hernández $A$, et al. Seroprevalencia de anticuerpos contra Trypanosoma cruzi y su asociación con factores de riesgo en menores de 18 años de Veracruz México. Rev Panam Salud Pública. 2007a;22:75-82.

Salazar-Schettino PM, Rojas-Wastavino G, Cabrera-Bravo M, Bucio-Torres M, GuevaraGómez $\mathrm{Y}$, et al. Epidemiología de la enfermedad de Chagas en el estado de Veracruz. Salud Pública de México. 2005b; 47: 201-8.

Salazar-Schettino PM, de Haro I, Cabrera M. Tres especies de Triatominos y su importancia como vectores de Trypanosoma cruzi en México. Medicina (Buenos Aires). 2005a; 65: 63-9.

Salazar-Schettino PM, Cravioto A, Tapia-Conyer R. Iniciativa México: Propuesta para el control 
y vigilancia epidemiológica de la enfermedad de Chagas en México. Bol Chil Parasitol. 2001; 57: 76-9.

Salazar-Schettino PM, Ruíz-Hernández A, de Haro-Arteaga I, Tay J, Gutiérrez-Quiroz M. Serología y electrocardiografía en jóvenes de área endémica de enfermedad de Chagas. Rev Med IMSS México. 1989; 27:59-65.

Salazar-Schettino PM, de Haro-Arteaga I, Uribarren-Berrueta T. Chagas disease in México. Parasitology Today. 1988; 4: 348-52.

Salazar-Schettino PM, Tay-Zavala J, RuízHernández A, de Haro-Arteaga I, Bucio M, et al. Seropositividad a Trypanosoma cruzi en cuatro grupos de población del estado de Oaxaca. Salud Pública México. 1984b; 26: 589-95.

Salazar-Schettino PM, Tay J, Bucio M, de HaroArteaga I, Anzures ME, Flores-Ayala S. Primer caso de megaesófago con serología positiva a Trypanosoma cruzi. Salud Pública de México. 1984a; 26: 452-5.

Salazar-Schettino PM, Castrejón J, Rodríguez HM, Tay J. Miocarditis chagásica crónica en México Tercer caso comprobado por exámenes parasitoscópicos. La Prensa Médica Revista Mexicana. 1979; 44: 115-20.

Sánchez B. Miocardiopatía Crónica e Infección por T. cruzi en una localidad de Morelos y Tabasco. Tesis de Licenciatura. Universidad Nacional Autónoma de México, Distrito Federal, México, 1988. 108 pp.

Sandoval-Ruíz C, Zumaquero-Rios JL, Linares G, Alejandre-Aguilar R, Cedillo ML, et al. (2004) Infección natural con Trypanosoma cruzi en triatominos (Hemiptera: Reduviidae: Triatomine) vectores de la enfermedad de Chagas en San Antonio Rayón Jonotla Puebla México. Tecnociencia. 2002;6:139-47.
Secretaria de Salud de Jalisco. Programa de Prevención y Control de Chagas Departamento de vectores y zoonosis. Dirección General de Salud Pública. Guadalajara, Jalisco, México; 2005.

Silveira AC, de Rezende DF, Correia MH. Risk measure of domestic transmission of Chagas disease through a new entomological indicator. Mem Inst Oswaldo Cruz. 1984; 79(Suppl): 113-15.

Tay-Zavala J, Salazar-Schettino PM; Ontiveros A, Jiménez J, de Haro-Arteaga I. Epidemiologic study of Chagas disease in a town in Oaxaca Mexico. PAHO Bull. 1986; 20(4): 358-65.

Tay-Zavala J, Salazar-Schettino PM, VelascoCedano M, de Haro-Arteaga I, García-Yáñez $\mathrm{Y}$, et al. Estudio Epidemiológico de la enfermedad de Chagas en el estado de Jalisco República Mexicana. Salud Pública de México. 1979; 21: 145-9.

Tay-Zavala J, Biagi F, de Buen AM. Estado actual de conocimientos sobre Triatomas $y$ enfermedad de Chagas en el Estado de Zacatecas. Medicina Revista Mexicana. 1968; 48:121-9.

Tay-Zavala J, Biagi F, de Buen AM). Estado actual de conocimientos sobre triatomas $y$ enfermedad de Chagas en el estado de Michoacán México. Rev Fac Med Mex UNAM México. 1967; 9: 109-21.

Tay-Zavala J, Biagi F, de Buen AM. Estado Actual de conocimientos sobre Triatoma del Estado de Morelos México. Revista de la Facultad de Medicina UNAM. 1966; 7: 451-61.

Tay-Zavala J, Biagi AM.) Localidades nuevas de triatominos mexicanos y su infección natural por Trypanosoma cruzi. Revista de la Facultad de Medicina UNAM México. 1964; 6: 305-11.

Trujillo-Contreras F, Lozano-Kasten F, SotoGutiérrez MM, Hernández-Gutiérrez R. 
Prevalencia de infección a Trypanosoma cruzi en donadores de sangre en el estado de Jalisco México. Revista de la Sociedad Brasileña de Medicina Tropical. 1993;26:89-92.

Velasco-Castrejón O, Valdespino-Gómez JL, Tapia-Conyer R, Salvatierra-Izaba B, GuzmánBracho C, et al.) Seroepidemiología de la Enfermedad de Chagas. Salud Pública de México. 1992; 34: 186-96.

Velasco-Castrejón O, Guzmán-Bracho C. Importancia de la Enfermedad de Chagas en México. Rev Latinoam de Microbiol. 1986; 28: 275-83.

Vidal-Acosta V, Ibañez-Bernal S, MartínezCampos C. Infección natural de chinches Triatominae con Trypanosoma cruzi asociadas a la vivienda humana en México. Salud Pública de México. 2000; 42: 496-03.

World Health Organization. Chagas disease: Central American initiative Launched. TDR News. 1998;55: 6.

World Health Organization. Andean Countries initiative launched in Colombia. TDR News. 1997;53:

World HealthOrganization. I Reunión de la Comisión Intergubernamental del Cono Sur para la eliminación de Triatoma infestans y la interrupción de la transmisión de la Tripanosomiasis Americana. Buenos Aires: OPS/HCP/HCT/PNSP/92. 1992;18.

3. Zárate LG, Zárate RG. A checklist of the Triatominae (Hemiptera: Reduviidae) of Mexico. Int J Entomol. 1985; 27: 102-27.

Zárate LG, Zárate RJ, Tempelis $\mathrm{CH}$, Goldsmith RS. The Biology and Behavior of

Triatoma barberi (Hemiptera: Reduviidae) in Mexico 1 Blood meal sources and infection whit Trypanosoma cruzi. J Med Entomol. 1980; 17: 103-16.

Zavala-Castro JE, Gutiérrez H, Barrera MA, Bolio A, Zavala-Velázquez JE. Cardiopatía chagásica crónica detectada en pacientes del Hospital General Regional O'Horan Mérida Yucatán México. Arch Inst Cardiol Mex. 1995;65:5415. 